\title{
Pengaruh Pemberian Aromaterapi Kayu Manis terhadap Intensitas Nyeri Dismenore Primer pada Remaja
}

\section{The Effect of Cinnamon Aromatherapy on The Intensity of Primary Dysmenorrhea Pain in Adolescents}

\author{
Ni Made Maharianingsih ${ }^{10}$, Ni Made Dewi Poruwati ${ }^{1}$ \\ ${ }^{1}$ Universitas Bali Internasional, Denpasar, Bali
}

\begin{abstract}
Abstrak: Gangguan haid akibat dismenore primer sering timbul pada usia remaja dengan prevalensi kejadian $89,5 \%$. Dismenore primer disebabkan oleh pelepasan prostaglandin yang berlebihan sehingga terjadi spasme uterus dan mengakibatkan nyeri saat menstruasi. Obat antiinflamasi nonsteroid (OAINS) sering digunakan untuk terapi awal mengurangi nyeri dismenorea primer, namun menimbulkan efek samping pada gastrointestinal. Penggunaan aromaterapi dengan essential oil dapat digunakan sebagai alternatif terapi selain obat untuk mengatasi dismenorea primer. Essential oil yang dapat digunakan adalah kayu manis yang memiliki efek antispasmodik melalui kandungan cinnamaldehyde (55-57\%) dan eugenol (5-18\%). Tujuan penelitian adalah mengetahui pengaruh pemberian aromaterapi kayu manis terhadap penurunan intensitas nyeri dismenore primer. Penelitian ini menggunakan rancangan pre-experimental design dengan metode one-group pretest-posttest design. Intensitas nyeri diukur dengan Wong Baker Rating Scale. Responden penelitian sebanyak 30 responden remaja yang merupakan siswi SMAN 1 Sukawati. Teknik pengambilan subjek dengan probability sampling. Analisa data menggunakan uji Wilcoxon. Diperoleh hasil yaitu sebelum pemberian aromaterapi kayu manis (pretest), responden mengalami intensitas nyeri ringan (10\%), sedang $(73 \%)$, dan berat $(17 \%)$. Setelah dilakukan pemberian aromaterapi kayu manis (posttest), responden mengalami penurunan intensitas nyeri dengan derajat nyeri ringan $(83 \%)$ dan sedang $(17 \%)$ dengan nilai $p=0,000$. Disimpulkan bahwa terdapat pengaruh signifikan pemberian aromaterapi kayu manis terhadap penurunan intensitas rasa nyeri pada remaja yang mengalami dismenore primer.
\end{abstract}

Kata Kunci: aromaterapi kayu manis, dismenore primer, intensitas nyeri

Abstract: Menstrual disorders due to primary dysmenorrhea often occur in adolescents with incidence prevalence $89.5 \%$ that is caused by the excessive release of prostaglandins, resulting in uterine spasm and resulting painful menstruation. Nonsteroidal anti-inflammatory drugs (NSAIDs) are often used for initial therapy to reduce primary dysmenorrhea pain, but have gastrointestinal side effects. The use of aromatherapy with essential oils can be used as an alternative therapy other than drugs to treat primary dysmenorrhea. Cinnamon is as essential oil can be used for an antispasmodic effect through cinnamaldehyde (55-57\%) and eugenol (5-18). The aim of this study was to determine the effect of cinnamon aromatherapy on reducing the pain intensity of primary dysmenorrhea. This study used a oneGroup pretest-posttest design. Pain intensity was measured by Wong Baker Rating Scale. Subject taking techniques with probability sampling by Wilcoxon test as data analysis by 30 adolescent who is students of SMAN 1 Sukawati. The results obtained were before giving cinnamon aromatherapy (pretest), respondents experienced mild pain intensity $(10 \%)$, moderate $(73 \%)$, and severe $(17 \%)$. After giving cinnamon aromatherapy (posttest), respondents experienced decrease in pain intensity with mild (83\%) and moderate pain levels $(17 \%)$ with $p=0.000$. It is concluded that there is significant effect of cinnamon aromatherapy to decrease pain intensity in adolescents with primary dysmenorrhea

Keywords: cinnamon aromatherapy, pain intensity, primary dysmenorrhea

\section{PENDAHULUAN}

Masa remaja merupakan masa transisi dari anak-anak menuju dewasa, dimana menurut WHO remaja adalah kelompok penduduk yang berada dalam rentang usia 10-19 tahun (Diananda, 2018). Pada masa ini perkembangan dan pertumbuhan

•email korespondensi: maharianingsih@iikmpbali.ac.id 
baik fisik ataupun mental terjadi begitu cepat (Lakhan, dkk., 2016). Perubahan karakterisik seksual menjadi salah satu contoh pertumbuhan dan perkembangan yang terjadi pada remaja. Pada remaja putri perubahan tersebut dapat dilihat dari pembesaran buah dada, perkembangan pinggang, dan terjadinya haid atau menstruasi (Diananda, 2018).

Haid atau menstruasi merupakan perdarahan periodik dari rahim yang dimulai sekitar 14 hari setelah ovulasi secara berkala akibat dari lapisan endometrium uterus yang lepas (Sinaga, 2017). Kondisi tesebut terjadi apabila pembuahan pada sel telur oleh sprema tidak terjadi, sehingga dinding rahim (endometrium) yang telah menebal menjadi luruh (Puspita, 2018). Gangguan pada menstruasi dengan prevalensi terbesar adalah dismenore yaitu sebesar 89,5\%. Dismenore dapat digambarkan sebagai rasa nyeri yang timbul pada saat menstruasi akibat dari pelepasan prostaglandin yang berlebihan sehingga menyebabkan kenaikan dari kontraksi uterus dan mengakibatkan nyeri pada saat menstruasi (Yunianingrum, 2018).

Dismeore terbagi dalam 2 jenis yaitu dismenore primer dan dismenore sekunder. Dismenore primer adalah nyeri haid tanpa kelainan pada alat-alat genital yang nyata dan terjadi beberapa waktu setelah menarche (menstruasi yang pertama kali), dan berdasarkan data dari di Indonesia angka kejadian dismenorea primer pada remaja adalah sekitar 54,89\% (Nurwana dan Andi, 2016). Dengan melihat tingginya angka kejadian dismenore primer pada remaja maka perlu dilakukan penanganan untuk menghilangkan gejala atau rasa sakit yang dirasakan. Hal tersebut dapat diatasi dengan mengkonsumsi Non-Steroidal Anti Inflammatory Drug (NSAID). NSAID adalah terapi yang digunakan untuk penanganan dismenore primer, dimana $67 \%$ wanita mengalami penurunan nyeri dismenore setelah menggunakan NSAID, namun penggunaan NSAID dilaporkan banyk menimbulkan efek samping seperti pada gastrointestinal dapat menimbulkan efek berupa mual, muntah, diare, dan nyeri pada ulu hati (Michelle, Farquhar, \& Chyntia, 2006).
Dismenore primer tidak hanya dapat ditangani secara farmakologi, pemberian terapi secara non-farmakologi juga dapat dilakukan. Salah satu penanganan non-farmakologi untuk mengatasi dismenore primer adalah dengan menggunakan aromaterapi. Aromaterapi kayu manis adalah salah satu aromaterapi yang dapat dipilih untuk penanganan dismenore primer pada remaja putri. Aromaterapi kayu manis mengandung komponen utama yaitu cinnamaldehyde (55-57\%) dan eugenol (5-18\%). Cinnamaldehyde memiliki aktivitas sebagai antispasmodik yang dapat meredakan kram perut serta eugenol yang dapat mencegah sintesis prostaglandin dan mengurangi peradangan (Jaafarpour, et. al, 2015). Berdasarkan uraian tersebut dilakukan penelitian untuk mengetahui pengaruh pemberian aromaterapi kayu manis terhadap intensitas nyeri siswi remaja yang mengalami dismenore primer sebelum dan setelah pemberian aromaterapi kayu manis.

\section{METODE PENELITIAN}

Penelitian ini termasuk dalam penelitian pre-eksperimental dengan metode one group pretest-posttest design. Penelitian ini telah mendapatkan persetujuan komisi etika penelitian Universitas Bali Internasional dengan nomor: 02.057/UNBI/EC/VII/2020. Instrument penelitian berupa kuesioner tingkat pengetahuan responden sebelum pemberian aromaterapi kayu manis dan pengukuran skala nyeri menggunakan Wong Baker Rating Scale. Bahan penelitian yang digunakan adalah essential oil kayu manis dengan nomor batch NAR030060-190418 yang di beli dari PT. Sura Dupa Spice. Lokasi penelitian bertempat di SMA Negeri 1 Sukawati pada bulan Februari-Mei 2020. Responden dalam penelitian ini adalah remaja yang merupakan siswi yang bersekolah di SMA Negeri 1 Sukawati yang mengalami dismenore primer. Teknik pengambilan sampel yang digunakan adalah nonprobability sampling yaitu purposive sampling. Jumlah sampel dalam penelitian ini adalah 30 responden yang mengalami dismenore primer, dengan kriteria inklusi: 1) Bersedia untuk dijadikan sampel penelitian, 2) Mengalami dismenore primer, 3) Tidak 
mengkonsumsi analgetik selama penelitian, 4) Tidak menggunakan aromaterapi lain selama penelitian, 5) Lama menstruasi tidak lebih dari 7 hari. Kriteria eksklusi: 1) para siswi yang tidak menyukai dan alergi terhadap aromaterapi kayu manis. Teknik analisis data yang digunakan adalah teknik analisis komparatif berkolerasi (perbandingan) antara intensitas nyeri sebelum dan sesudah pemberian intervensi aromaterapi kayu manis.

\section{HASIL DAN PEMBAHASAN}

Gambaran karakteristik responden yang meliputi usia, riwayat keluarga, dan tindakan penanganan dismenore primer (sebeum intervensi) dapat dilihat dalam tabel berikut.

Tabel 1 Karakteristik Responden

\begin{tabular}{|c|c|c|c|}
\hline No. & Karakteristik & $\begin{array}{l}\text { Jumlah } \\
(n=30)\end{array}$ & (\%) \\
\hline \multicolumn{4}{|c|}{1 Usia } \\
\hline & a. 16 tahun & 4 & 13 \\
\hline & b. 17 tahun & 19 & 63,33 \\
\hline & c. 18 tahun & 7 & 23 \\
\hline \multicolumn{4}{|c|}{ 2. Riwayat keluarga } \\
\hline & a. Dismenore & 21 & 70 \\
\hline & b. Tidak dismenore & 9 & 30 \\
\hline \multirow[t]{8}{*}{3.} & $\begin{array}{l}\text { Tindakan penanganan dismenore primer } \\
\text { (sebelum intervensi) }\end{array}$ & & \\
\hline & $\begin{array}{l}\text { a. Menggunakan obat } \\
\text { b. Tidak menggunakan obat }\end{array}$ & 2 & 7 \\
\hline & - olahraga ringan & 0 & 0 \\
\hline & - kompres air hangat & 5 & 17 \\
\hline & nomizan & 5 & 17 \\
\hline & - $\quad$ pemijatan di bagian nyeri & 12 & 40 \\
\hline & - olahraga ringan dan kompres air hangat & & \\
\hline & - kompres air hangat dan pemijatan & 6 & 20 \\
\hline
\end{tabular}

Berdasarkan hasil penelitian, diperoleh hasil usia responden yang paling banyak mengalami dismenore primer di SMA Negeri 1 Sukawati adalah responden yang berusia 17 tahun. Hal ini sesuai dengan studi yang telah dilakukan di Amerika Serikat dimana prevalensi dismenore primer pada wanita yang berusia 17 tahun adalah $59,7 \%$. Hal ini juga disebutkan dalam penelitian yang telah dilakukan di Indonesia pada tahun 2016 dimana terdapat $54,89 \%$ wanita yang berada dalam rentang usia 15-18 tahun mengalami dismenore primer (Nurwana dan Andi, 2016).

Riwayat keluarga merupakan salah satu faktor risiko yang dapat meningkatkan kemungkinan terjadinya dismenore primer. Dua dari tiga wanita yang menderita dismenore primer mempunyai riwayat keluarga positif mengalami dismenore primer (Handayani, Eka, \& Rahayu, 2014). Berdasarkan hasil penelitian, siswi SMA
Negeri 1 Sukawati diperoleh hasil sebanyak 21 orang (70\%) responden memiliki riwayat keluarga yang megalami dismenore primer, sehingga hal tersebut dapat menjadi faktor risiko dismenore primer yang dialami oleh responden. Hasil penelitian ini sejalan dengan penelitian yang dilakukan oleh Handayani, Eka, dan Rahayu (2014) dimana didapatkan hasil penelitian sebenyakan 38 orang (95\%) responden yang mengalami dismenore primer memiliki riwayat keluarga positif dismenore primer. Sedangkan 9 orang (30\%) responden tidak memiliki riwayat keluarga yang mengalami dismenore primer.

Siswi SMA Negeri 1 Sukawati menangani dismenore primer yang dialami dengan beberapa cara baik farmakologi dengan menggunakan obat analgetik terutama golongan NSAID atau nonfarmakologi. Dari hasil penelitian didapatkan bahwa sebanyak 2 orang (7\%) responden 
menggunakan Asam mefenamat, namun penggunaan asam mefenamat untuk mengurangi intensitas dismenore primer dilaporkan dapat memberikan beberapa efek samping seperti mual, muntah, dan sembelit. Sedangkan 28 (93\%) responden menggunakan terapi non- farmakologi.

Terapi non-farmakologi yang digunakan responden diantaranya adalah kompres air hangat yang mampu memberikan efek vasodilatasi atau pelebaran pembuluh darah, sehingga dapat memberikan respon relaksasi otot dan menurunkan nyeri. Selain itu dengan melakukan kompres air hangat tubuh akan dapat menghasilkan endorphin yang dapat berfungsi sebagai penenang alami yang dapat menimbulkan rasa nyaman dan dapat menurunkan ketegangan pada otot sehingga dapat mengurangi rasa nyeri
(Putri, Dewi, dan Yuliani, 2017). Selain kompres air hangat melakukan olahraga ringan seperti lari dan senam yang cukup dan teratur juga mampu mengatasi intensitas nyeri dismenore primer hal ini dapat terjadi karena melalui olahraga ringan tersebut dapat meningkatkan kadar hormon endorfin yang berperan sebagai natural pain killer (Putri, Dewi, dan Yuliani, 2017). Teknik pemijatan di bagian nyeri saat mengalami dismenore primer juga mampu mengurangi intensitas nyeri, dengan melakukan teknik pemijatan pada area nyeri dapat mengakibatkan terjadinya pelepasan hormon endorphin yang akan menyebabkan berkurangnya rasa nyeri (Hikmah, Coryna, \& Dewi, 2018; Rakhma, 2006). Tingkat pengetahuan responden sebelum pemberian aromaterapi kayu manis (Cinnamomum burmanii L.) tersaji dalam tabel 2.

Tabel 2 Tingkat Pengetahuan Responden Sebelum Pemberian Aromaterapi Kayu Manis

\begin{tabular}{ccccc}
\hline No Butir Soal & Jawaban Responden & Jumlah $(\mathbf{n}=\mathbf{3 0})$ & (\%) \\
\hline \multirow{2}{*}{1} & a. & Salah & 0 & 0 \\
& b. & Benar & 30 & 100 \\
\hline \multirow{2}{*}{2} & a. & Salah & 0 & 0 \\
& b. & Benar & 30 & 100 \\
\multirow{2}{*}{3} & a. & Salah & 0 & 0 \\
& b. & Benar & 30 & 100 \\
\hline \multirow{2}{*}{4} & a. & Salah & 0 & 0 \\
& b. & Benar & 30 & 100 \\
\hline \multirow{2}{*}{5} & a. & Salah & 0 & 0 \\
& b. & Benar & 30 & 100 \\
\hline \multirow{2}{*}{6} & a. & Salah & 2 & 6,7 \\
& b. & Benar & 28 & 93,3 \\
\hline \multirow{2}{*}{7} & a. & Salah & 0 & 0 \\
& b. & Benar & 30 & 100 \\
\hline \multirow{2}{*}{8} & a. & Salah & 1 & 3,3 \\
& b. & Benar & 29 & 96,7 \\
\multirow{2}{*}{9} & a. Salah & 1 & 3,3 \\
& b. & Benar & 0 & 96,7 \\
\hline \multirow{2}{*}{10} & a. Salah & 30 & 0 \\
& b. & Benar & 100 \\
\hline
\end{tabular}

Hasil kuesioner edukasi terkait pengaruh pemberian aromaterapi kayu manis untuk mengurangi dismenore primer terhadap 30 reponden didapatkan hasil bahwa sebanyak 26 orang (87\%) responden menjawab semua pertanyaan dengan benar, sedangkan 4 orang (13\%) responden lainnya masing-masing salah pada satu soal. Dengan hasil tersebut pengetahuan responden terkait penelitian pengaruh pemberian aromaterapi kayu manis untuk mengurangi nyeri dismenore primer dinyatakan baik hal ini sesuai dengan kriteria yang telah ditentukan yaitu apabila nilai persentase responden yang menjawab benar $>70 \%$ maka responden dinyatakan telah mengerti dan siap untuk intervensi yang akan dilakukan. 
Tabel 3 Hasil Analisis Deskriptif Intensitas Dismenore PrimerSebelum dan Sesudah Pemberian Aromaterapi Kayu Manis

\begin{tabular}{|c|c|c|c|c|c|}
\hline Nyeri Dismenore & $\begin{array}{c}\text { Jumlah } \\
\text { (n) }\end{array}$ & Min & $\operatorname{Max}$ & Mean & $\begin{array}{c}\text { Std. } \\
\text { Deviation }\end{array}$ \\
\hline $\begin{array}{lr}\text { Sebelum pemberian } \\
\text { aromaterapi } \quad \text { kayu } \\
\text { manis }\end{array}$ & 30 & 3,00 & 7,00 & 5,1667 & 1,0531 \\
\hline $\begin{array}{lr}\text { Setelah pemberian } \\
\text { aromaterapi kayu } \\
\text { manis }\end{array}$ & 30 & 1,00 & 5,00 & 3,2333 & 1.1043 \\
\hline
\end{tabular}

Berdasarkan tabel 3, didapatkan nilai ratarata intensitas dismenore primer SMA Negeri 1 Sukawati sebelum diberikan aromaterapi kayu manis adalah 5,1667 dengan mayoritas responden yang mengalami nyeri sedang yaitu sebanyak 22 orang (73\%) responden. Hal ini sesuai dengan penelitian yang dilakukan oleh Tarigan (2018) dimana mayoritas responden mengalami nyeri sedang sebelum diberikan aromaterapi kayu manis yaitu sebanyak 13 orang $(59,1 \%)$ responden.

Nyeri sedang yang dialami oleh sebagian besar responden dapat terjadi karena adanya berbagai faktor salah satunya adalah penilaian nyeri yang bersifat sangat subjektif dan invidual sehingga memiliki kemungkinan nyeri dalam intensitas yang sama dapat dirasakan berbeda oleh setiap individu yang berbeda (Rakhma, 2006). Selain itu respon nyeri yang timbul juga dapat dipicu karena adanya perasaan cemas dan stress. Kondisi stress tersebut dapat memengaruhi produksi hormon estrogen, progesterone, adrenalin dan prostaglandin yang dapat diproduksi secara berlebihan hal tersebut menyebabkan terjadinya kram perut bagian bawah yang akan merangsang nyeri saat menstruasi (Kimata, 2018).

Berdasarkan hasil penelitian yang telah dilakukan, didapatkan nilai rata-rata intensitas dismenore primer responden setelah diberikan aromaterapi kayu manis adalah 3,2333 dengan mayoritas responden yang mengalami nyeri ringan yaitu sebanyak 25 (83\%) responden, sisanya adalah nyeri sedang sebanyak $5(17 \%)$ responden. Hasil penelitian ini juga sesuai dan didukung oleh penelitian yang telah dilakukan oleh Tarigan (2018) dimana mayoritas responden mengalami penurunan intensitas nyeri setelah diberikan aromaterapi kayu manis, yaitu sebanyak 13 responden (59,1\%) mengalami nyeri ringan. Hasil penelitian ini sesuai dengan literatur dimana diketahui aromaterapi kayu manis kandungan kimia utama yaitu cinnamaldehyde (55-57\%) dan eugenol (5-18\%) (Jaafarpour, et. al, 2015).

Dengan adanya kandungan cinnamaldehyde yang memiliki aktivitas sebagai antispasmodik yang dapat meredakan kram perut serta eugenol yang dapat mencegah sintesis prostaglandin dan mengurangi peradangan dapat mengurangi intensitas nyeri dismenore primer yang dirasakan oleh responden (Evayanti, dkk., 2019). Aromaterapi kayu manis yang digunakan sebagai alternatif untuk menurunkan intensitas nyeri dismenore primer yang digunakan secara inhalasi bekerja dengan cara merangsang sel-sel reseptor penciuman dan impuls di transmisikan ke pusat emosional otak atau sistem limbik sehingga aromaterapi dapat memberikan efek menenangkan dan meningkatkan sirkulasi darah sehingga intensitas nyeri dismenore primer yang dirasakan dapat berkurang (Maharani, Fatmawati, \& Widyaningrum, 2016).

Tabel 4 Hasil Uji Normalitas

\begin{tabular}{lcc}
\hline \multicolumn{1}{c}{$\begin{array}{c}\text { Nyeri Dismenore } \\
\text { Primer }\end{array}$} & $\begin{array}{c}\text { Kolmogorov } \\
\text { Smirnov }\end{array}$ & Probabilitas \\
\hline $\begin{array}{l}\text { Sebelum pemberian } \\
\text { aromaterapi kayu } \\
\text { manis (Cinnamomum } \\
\text { burmanii L.) }\end{array}$ & 0,363 & 0,000 \\
$\begin{array}{l}\text { Setelah pemberian } \\
\text { aromaterapi kayu } \\
\text { manis (Cinnamomum } \\
\text { burmanii L.) }\end{array}$ & 0,350 & 0,000 \\
\hline
\end{tabular}

Berdasarkan tabel 4 diketahui bahwa hasil uji normalitas pada data intensitas dismenore primer sebelum dan setelah pemberian aromaterapi kayu 
manis diperoleh nilai statistik Kolmogorov-Smirnov berturut-turut sebesar 0,363 dan 0,350, dan probabilitas sebelum dan setelah pemberian aromaterapi kayu manis sebesar 0,000 dan 0,000 sehingga data intensitas dismenore primer tersebut dinyatakan tidak terdistribusi normal, karena uji prasyarat tidak terpenuhi maka dipilih uji nonparametrik yaitu uji Wilcoxon. Hasil Uji Pengaruh Pemberian Aromaterapi Kayu Manis (Cinnamomum Burmanii L.) Terhadap Intensitas Dismenore Primer tersaji dalam tabel 5.

Tabel 5 Hasil Uji Pengaruh Pemberian Aromaterapi Kayu Manis terhadap Intensitas Dismenore Primer

\begin{tabular}{lccc}
\hline $\begin{array}{l}\text { Nyeri Dismenore } \\
\text { Primer }\end{array}$ & $\begin{array}{c}\text { Rata- } \\
\text { Rata }\end{array}$ & $\begin{array}{c}\text { Wilcoxon } \\
\text { Test }\end{array}$ & Probabilitas \\
\hline $\begin{array}{l}\text { Sebelum } \\
\text { pemberian }\end{array}$ & & & \\
$\begin{array}{l}\text { aromaterapi kayu } \\
\text { manis }\end{array}$ & 5,1667 & $-5,385$ & 0,000 \\
$\begin{array}{l}\text { Setelah } \\
\text { pemberian } \\
\text { aromaterapi kayu } \\
\text { manis }\end{array}$ & 3,2333 & & \\
\hline
\end{tabular}

Berdasarkan tabel 5 dapat dilihat jika data yang telah diuji dengan menggunakan analisis nonparametrik yaitu dengan Wilcoxon test, sehingga diperoleh hasil uji Z yaitu sebesar -5,385 dengan probabilitas sebesar 0,000. Apabila probabilitas $\leq$ level of significance $(\alpha=5 \%)$ maka $\mathrm{H} 1$ diterima. Hal tersebut berarti terdapat pengaruh yang signifikan pada pemberian aromaterapi kayu manis tehadap intensitas dismenore primer siswi SMA Negeri 1 Sukawati. Hal ini sesuai dengan penelitian yang dilakukan oleh Tarigan (2018), dimana didapatkan hasil $p=0,000$ pada uji statistik independent t-test yang berarti terdapat pengaruh pemberian aromaterapi kayu manis terhadap intensitas dismenore primer pada siswi SMA Al-Ulum Medan (Tarigan, 2018).

Penggunaan aromaterapi dengan cara inhalasi merupakan salah satu teknik yang dapat digunakan untuk mengatasi dismenore primer. Seorang ahli kimia pada tahun 1928 yang bernama Rene-Maurice Gattefoss mengklaim bahwa penggunaan aromaterapi berupa minyak essensial murni apabila digunakan dengan benar mampu menimbulkan efek positif terhadap psikologis dan fisik (Tarigan, 2018).
Pemberian aromaterapi kayu manis berpengaruh dalam menurunkan intensitas dismenore primer siswi SMA Negeri 1 Sukawati. Hal ini disebabkan karena aromaterapi kayu manis yang digunakan secara inhalasi akan bekerja melalui sirkulasi tubuh dan sistem penciuman, dimana apabila aromaterapi terhirup ke rongga hidung melalui pernafasan, akan diterjemahkan oleh otak sebagai proses penciuman dan terjadi proses penerimaan molekul aromaterapi tersebut oleh saraf olfactory epthelium, kemudian ditransmisikan sebagai pesan ke pusat penciuman yang terletak di bagian belakang hidung. Sel neuron mengintrepretasi aroma tersebut dan meneruskan ke sistem limbik yang kemudian akan di kirimkan ke hipothalamus sehingga dapat merangsang hipotalamus untuk melepaskan hormon serotonin yang dapat memperbaiki suasan hati dan hormon endorphin yang berfungsi sebagai penghilang rasa sakit alami, menimbulkan pesaan rileks, tenang, dan senang sehingga dapat memengaruhi intensitas dismenore primer yang dirasakan (Tarigan, 2018).

\section{SIMPULAN}

Berdasarkan hasil penelitian yang telah dilakukan dapat ditarik kesimpulan bahwa terdapat pengaruh signifikan pemberian aromaterapi kayu manis terhadap penurunan intensitas rasa nyeri pada remaja yang mengalami dismenore primer dan memperkuat hasil penelitian sebelumnya. Rata-rata penurunan skala nyeri yang diperoleh sebelum pemberian intervensi adalah 5,1667 sedangkan setelah pemberian intervensi adalah 3,2333, nilai tersebut menunjukkan adanya penurunan dua skala.

\section{UCAPAN TERIMA KASIH}

Penulis mengucapkan terimakasih kepada pihak yang mendukung terselesaikannya penelitian ini yaitu pada Universitas Bali Internasional, siswi di SMAN 1 Sukawati yang beredia menjadi responden dalam penelitian ini serta pihak sekolah yang memberikan ijin penelitian. 


\section{DAFTAR PUSTAKA}

Diananda, A. 2018. Psikologi Remaja dan Permasalahannya. (serial online), [Cited, 2019 Jan]. Available from: URL:httpejournal.stit-islamicvillage.ac.id/index.php/istighna

Evayanti, Yulistiana, Hidayat, dan Andayani. 2019. The Effect of Cinnamon on Pain Among Teenage Girls with Primary Dysmenorrhea in Lampung-Indonesia. Malahayati University

Handayani, Eka Y., dan Rahayu, L.S. 2014. FaktorFaktor yang Berhubungan dengan Nyeri Menstruasi (Dismenore) pada Remaja Putri di Beberapa SMA di Kabupaten Rokan Hulu. Universitas Pasir Pengaraian

Hikmah, Coryna R.A., dan Dewi A. 2018. Pengaruh Pemberian Massage Effleurage Menggunakan Minyak Aromaterapi Mawar terhadap Penurunan Intensitas Nyeri Dismenore pada Remaja Di SMK Negeri 2 Malang Jurusan Keperawatan. Universitas Brawijaya

Jaafarpour, M. et al. 2015. The Effect of Cinnamon on Menstrual Bleeding and Systemic Symptoms with Primary Dysmenorrhea. Department of Midwifery, Nursing and Midwifery Faculty, Ilam University of Medical Sciences

Kimata, D.A.N. 2018. Gambaran Tingkat Stress Psikologis dan Tingkat Dysmenorrhea Primer Pada Mahasiswi Fisioterapi S1 Di Universitas Muhammadiyah Surakarta. Surakarta: Program Studi Fisioterapi Fakultas IImu Kesehatan Universitas Muhammadiyah Surakarta

Lakhan, Shaheen E., Sheafer, Heather., dan Tepper, D. 2016. The Effectiveness of Aromatherapy in Reducing Pain: A Systematic Review and Meta-Analysis. Global Neuroscience Initiative Foundation, Los Angeles, CA, USA

Maharani, Y.N., Fatmawati, E., dan Widyaningrum, R. 2016. Pengaruh Aromaterapi Bunga Lavender (Lavandula angustifolia) Terhadap Intensitas Nyeri Haid (Dismenore) Pada Mahasiswi STIKES Madani Yogyakarta. Yogyakarta
Michelle P., dan Farquhar, Chyntia. 2006. Diagnosis and Management of Dysmenorrhea. British Medical Journal

Nurwana., Y.S., dan Andi F.F. 2016. Analisis Faktor yang Berhubungan dengan Kejadian Dismenore pada Remaja Putri di SMA Negeri 8 Kendari Tahun 2016. Fakultas Kesehatan Masyarakat Universitas Halu Oleo

Puspita S.C.F. 2018. Gambaran Lama Menstruasi pada Remaja. Surakarta: Universitas Muhammadiyah

Putri, R.Y., Dewi, R. dan Yuliani. 2017. Efektifitas Pengaruh Abdominal Stretching Exercise dan Kompres Hangat terhadap Intensitas Nyeri Dismenore. STIkes Fort de Kock Bukittinggi

Rakhma, A. 2006. Gambaran Derajat Dismenore dan Upaya Penanganannya pada Siswi Sekolah Menengah Kejuruan Arjuna Depok Jawa Barat. Fakultas Kedokteran dan IImu Kesehatan Universitas Islam Negeri Syarif Hidayatullah Jakarta.

Sinaga, Er. 2017. Manajemen Kesehatan Menstruasi. Universitas Nasional.

Tarigan, D.A.P. 2018. Pengaruh Pemberian Aromaterapi Kayu Manis (Cinnamomum Burmanni) terhadap Derajat Dismenore Primer pada Siswi SMA Swasta Al-Ulum Medan. Universitas Sumatera Utara.

Yunianingrum, E. 2018. Pengaruh Kompres Hangat dan Aromaterapi Lavender Terhadap Penurunan Nyeri Dismenore Primer Pada Remaja Putri Di Pondok Pesantren As Salafiyyah Dan Pondok Pesantren AshSholihah Sleman. Politeknik Kesehatan Kementrian Kesehatan Yogyakarta. 